国内 9 ヶ所のダム湖における水温傾向の評価に関する予備的研究

長尾正之 ${ }^{1)} \cdot$ 鈴木 淳 $^{1)}$

\title{
Preliminary study of recent water temperature trends of nine dam reservoirs in Japan
}

\author{
Masayuki NAGAO ${ }^{1)}$ and Atsushi SUZUKI ${ }^{1)}$
}

\begin{abstract}
In order to investigate the impact of global warming on the inland waters of Japan, we examined the rates of rises in water temperature in nine dam reservoirs that had kept long-term records of vertical temperature observations. Water temperatures at the shallowest and deepest layers were selected as being representative for our investigation, and their trend lines were obtained using time-series analysis. Our first expectation was that the deepest water temperatures would be little-affected by meteorological disturbances and might even show clearer temperature rises than those in the shallowest water. However, all the nine reservoir trend lines from 1993 to 2006 in the shallowest layers showed an upward tendency probably attributable to recent rises in air temperature. In some reservoirs, the ratio of water temperature rises exceeded the ratio of rises in air temperature. In contrast, trend lines of the deepest layers during the same period revealed both upward and downward tendencies. Those results suggested that water temperatures in the deepest layers were affected by a reduction in volume due to accretions of sand, enhanced stratification, or diminished vertical mixing, rather than to a rise in temperature due to a concomitant rise in air temperature. To determine the impacts of these effects will be an important issue in future investigation.
\end{abstract}

Key words: water temperature, dam reservoir, global warming, trend analysis, seasonal adjustment method.

\section{摘 要}

日本のダム湖で温暖化による水温上昇が認められるかどうかを調べるため, 水温多層観測が長期間な されているダム湖 9 箇所を選び，最表層と最下層の水温傾向を時系列解析で抽出し，水温上昇率を調へ た。当初, 気象擾乱の影響を受けにくい最下層で, 温暖化による水温上昇が明瞭に認められると予想し た。しかし, 逆に最下層よりも最表層の水温に, 水温上昇が明瞭に認められた。すなわち, 最表層水温は, 1993 年から 2006 年において 9 つのダム湖すべてで上昇傾向にあった。この結果は, 最表層水温が気温 上昇の影響を強く受けているためと考えられたが，気温上昇率を上回る水温上昇率を持つダム湖もあっ た。一方，同期間の最下層水温については，上昇傾向と下降傾向にあるダム湖が存在した。最下層水温 は気温上昇に伴うダム湖全体の水温上昇よりも，湖底上昇によるダム容量の減少，成層強化，冬季鉛直 混合の低下に影響を受けている可能性が示唆され，その分離が今後の課題となった。

\footnotetext{
1) 産業技術総合研究所 地質情報研究部門, $\mathbf{T} 305-8567$ 茨城県つくば市東 1-1-1 中央第 7 Institute of Geology and Geoinformation, National Institute of Advanced Industrial Science and Technology (AIST), Tsukuba Central 7, Higashi 1-1-1, Tsukuba, Ibaraki 305-8567, Japan （連絡先長尾正之 $\bowtie$ nagao-masayuki@aist.go.jp）
} 
キーワード : 水温, ダム湖, 温暖化, トレンド解析, 季節調整法

(2009 年 3 月 5 日受付； 2009 年 11 月 10 日受理)

\section{はじめに}

気温や水温の長期変動は, 環境変化の指標として常に 研究の対象となってきた。IPCC 第 2 作業部会第 4 次調 査報告書（IPCC,2007）によれば，ダム湖，湖沼で温暖 化の影響が進行し, 表面水温が上昇すると, 藻類の増殖 を引き起こし（Hall et al., 2002; Kumagai et al., 2003), 塩 素処理された飲み水の悪臭や味の悪さの発生につながる 恐れがあること，(Moulton and Cuthbert, 2000; Robarts et al., 2005), この問題は既存の水道技術では解決できない 恐れがあること (Charlton et al., 2001) が指摘されている。 近年の国内湖沼の水温変化と環境変化の対応例として は, 茨城県霞ヶ浦の化学的酸素要求量 (COD) の数值が, 2005 年度 $\left(7.6 \mathrm{mg} \mathrm{L}^{-1}\right), 2006$ 年度 $\left(8.2 \mathrm{mg} \mathrm{L}^{-1}\right), 2007$ 年 度 $\left(8.8 \mathrm{mg} \mathrm{L}^{-1}\right), 2008$ 年度 $\left(8.7 \mathrm{mg} \mathrm{L}^{-1}\right)$ にかけて漸増傾 向にあることが挙げられる（茨城県生活環境部環境対 策課，2007, 2008, 2009)。このうち，2005 年度から 2006 年度の COD 増加については, 秋口から春の気温が平年 より高く, これが水温上昇を引き起こし植物プランクト ンの湖内生産を活発にしたためと考えられている（茨城 県生活環境部環境対策課, 2007)。このほか, 琵琶湖では, 2007 年 1 月〜 3 月に暖冬のため全循環が遅れたために, 貧酸素状態が継続した（岡本ら，2007）。

地球温暖化に対する陸水温度の応答について, 新井 （2000）は既往研究を総評し，河川・湖沼ともに水温上 昇は気温上昇よりは小さいこと, 湖沼の循環型が変わる 可能性があること, 水温成層が強くなること等が予測さ れるとしている。しかし同時に，基礎となる観測值が非 常に少なく予測を困難にしていることも指摘している。 また, 取り上げられている研究の多くは湖沼, 河川であっ た。日本を代表する湖である琵琶湖については, 1964 年から 1997 年までの琵琶湖北湖深層水温の上昇率が 0.40 ${ }^{\circ} \mathrm{C}(10 \mathrm{y})^{-1}$ であり, 直近の彦根の月平均気温の上昇率 0.30 ${ }^{\circ} \mathrm{C}$ (10y) $)^{-1}$ を上回っていたことが, 速水・藤原 (1999) により報告されている。

一方, 国内の主要ダム湖では定期水温観測が行わ れ，その結果は多目的ダム管理年報（建設省河川局， 1959-1992）やダム諸量データベース（国土交通省）に 公表されている。たとえば池浦ら（2008）は，1962 年 1 月〜 2008 年 2 月の日向神ダム湖水温の経年変動を調べ,
底層水温は $0.88{ }^{\circ} \mathrm{C}(10 \mathrm{y})^{-1}$ の割合で上昇していること を明らかにした。この值は, ダムの年平均気温の上昇率 $0.32{ }^{\circ} \mathrm{C}(10 \mathrm{y})^{-1}$ を上回っていた。湖のスケールの違いや データ解析期間の違いはあるが, 池浦ら（2008）の結果 は, 速水・藤原 (1999) の結果と同様に, 気温上昇率を 上回る水温上昇率をダム湖が示す場合があることを示唆 している。

池浦ら（2008）の研究のように, 国内ダム湖の水温観 測記録を使えば, 水温経年変動について調べることが できるが, 筆者が調べた範囲では, 池浦ら（2008）の研 究以外にダム湖水温の経年変動の研究は認められなかっ た。ダム湖水温上昇率の研究例が少ない理由は, 自然湖 沼に比べて, 堆砂によるダム湖容積の縮小や, 人為的な 水位操作による変動が激しいため, 取り扱いが困難だか らだと想像された。

そこで, 本研究では, 季節要因や短期変動の影響を避 け，傾向成分だけを抽出できる時系列解析法を使い，全 国 9 つのダム湖の最表層と最下層の水温の傾向について 解析を試みた。

\section{材料と方法}

\section{データの出典と解析対象ダム}

原則として毎月観測されている 1959 年から 2006 年ま での多層水温データを, 多目的ダム管理年報（建設省河 川局, 1959-1992）とダム諸量データベース（国土交通省） の水温年表から選び，解析に用いた。

水温上昇率の評価は, 長期的傾向と短期的傾向の二つ の見方で行った。長期的傾向については, 1970 年代以 前から水温が記録されているダム湖について, 竣工時か ら現在までの水温傾向について調べた。一方, 水温上昇 率を比べるためには，記録期間がダム湖間でそろってい る必要がある。そこで, 短期的傾向については, 記録期 間を 1993 年から 2006 年の 14 年間に固定し, 水温傾向 を調べた。

Fig.1 に解析対象のダム湖の位置を示した。短期的な 傾向を解析するためにダム湖は, 北海道, 東北, 関東, 中部, 関西, 中・四国, 九州, 沖縄から代表的なものを 選んだ。長期的な水温傾向を調べるために, 選んだダム 湖のダム名 (都道府県名) は, 桂沢 (北海道), 釜房 (宮 
国内 9 ケ所のダム湖における水温傾向の評価に関する予備的研究

Table 1 Specifications of analyzed dam reservoirs.

表 1 解析対象としたダム湖の諸元.

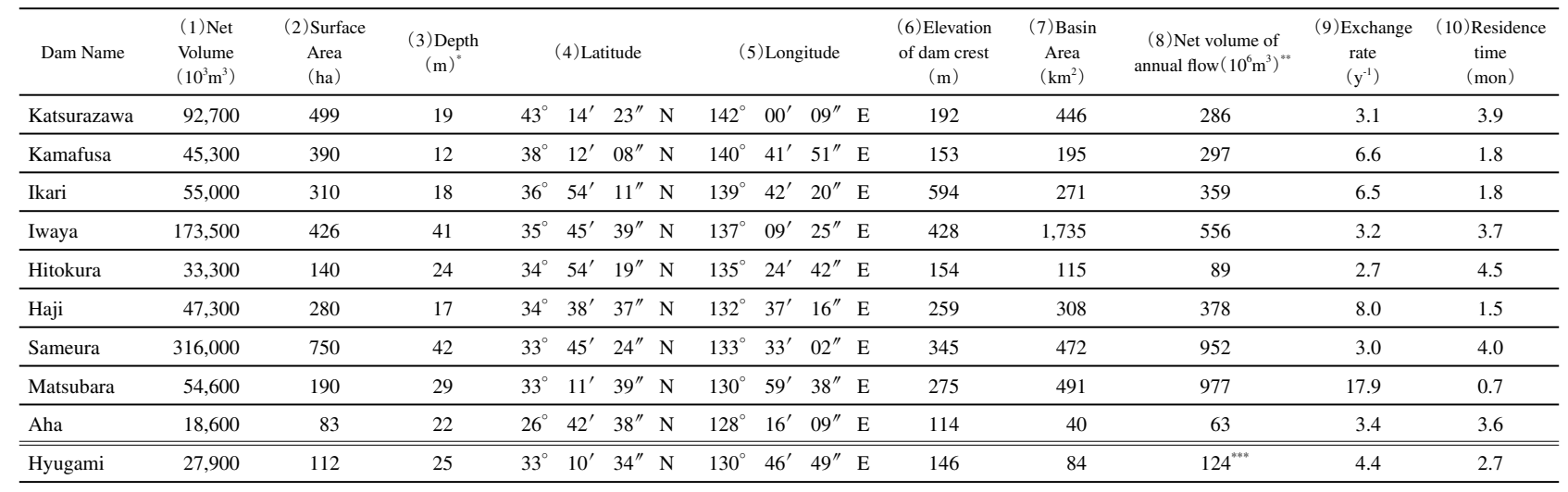

(1) and (2) were quoted from "Dams Yearbook 2008 (Damu Nenkan 2008)" (Japan Dam Foundation, 2008). (4)-(7) were quoted from "Dam Handbook (Damu Binran)" (Japan Dam Association).

${ }^{*}(3)=(1) /(2) .^{* *}(8)$ is based on average annual flows from 1993 to 2007 taken from "Database of Dams (Damu Shoryou de-tabe-su)" (Ministry of Land, Infrastructure, Transport and Tourism).

**** Calculated by net volume of annual flow at Hunagoya, and ratio of cachment area between Yabe River and Hyugami Dam. Net volume at Hunagoya and cachment area were obtained from "Rivers in Japan (Nihon Kasenzu)" (Japan River Association).

城), 五十里（群馬）である。各ダムの諸元は Table 1 に まとめた。

\section{水温傾向の調査方法}

\section{データの前処理}

水温年表を精査し異常值を発見した場合は，欠測扱い とした。たとえば，小数点記入もれが原因で，ある深度 の水温がその上と下の水温に比べて 10 倍程度高い場合 は，その深度の水温は欠測扱いとした。

また，観測日の水位も精査した。水面ではなく基準面 を基準にして等水温図を作る際に，観測日の水位が必要 となるためである。観測日の水位が欠測，あるいは異常 值と考えられる場合は，多目的ダム管理年報，またはダ ム諸量データベースの貯水位・流入量・放流量年報の日 平均水位を代入した。また，ある月の水温観測が行われ ていない場合は，その月の平均水位を代入した。

\section{解析対象水温}

本研究では, 水温年表に記載されている最表層水温と 最下層水温を, 解析対象とした。ここで, 最表層水温は, 水温年報に記載されている水温測定層のうち, もっとも 上の層の水温である。そして，最表層水温は，気温の年 変動の影響を強く受ける層である。最下層水温は，水温 年報に記載されている水温測定層のうち, もっとも下の 層の水温であり, 気温変動の影響が極小な層と考えられ

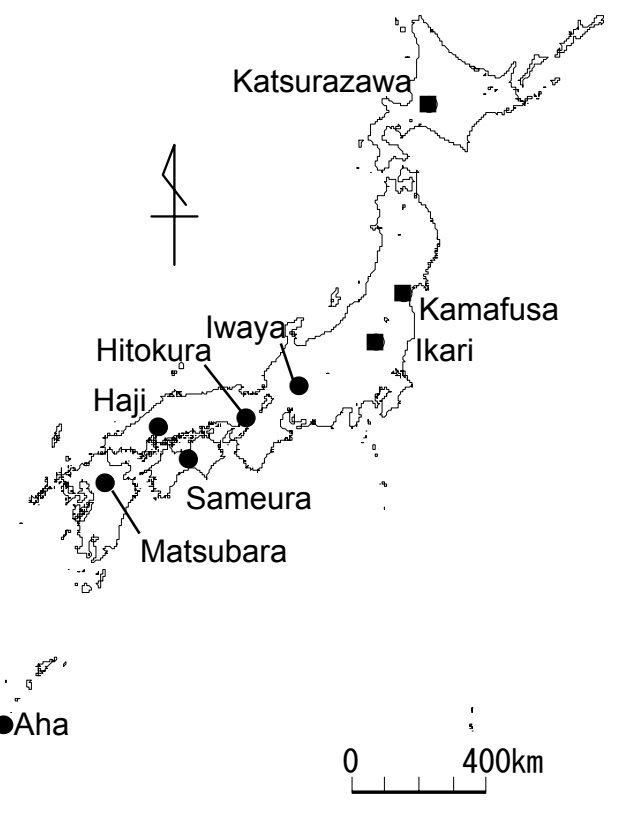

Fig.1. Locations of analyzed dam reservoirs. Closed squares denote reservoirs utilized for long/short-term trend analyses. Closed circles ( ) denote reservoirs utilized only for short-term trend analyses. Locations are quoted from "Dam Handbook(Damu Binran)" (Japan Dam Association).

図 1 解析対象のダム湖の位置. 水温の長期的傾向と短期的 傾向の両方を調べたダム湖はロで, また, 短期的傾向だ けを調べたそれ以外のダム湖はので示している. ダム湖 位置は，「ダム便覧」（日本ダム協会）から引用。 
る。

\section{水温上昇率の決定方法}

池浦ら（2008）は日向神ダムの水温時系列に対して線 形一次回帰直線をあてはめて, 水温上昇率を計算してい る。この方法では水温時系列の傾向成分（トレンド）を 求めることができない。傾向成分を知るには, 自然由来 の熱収支と人為的水位操作に伴う季節変動成分を除く必 要がある。

経済統計分析では月次データから季節要因を取り 除くために，季節調整法が用いられる。TIMSAC for R package（統計数理研究所）の decomp (Akaike et al., 1985）は季節調整法の一種で，月次データから季節要因 を取り除くほか, 短期的な変動成分も取り除き，長期的 変動成分を傾向成分として抽出できる。 decomp では, 月水温データ $y(t)$ を，

$y(t)=T(t ; k)+S(t ; l)+A R(t ; m)+W(t)$

の季節調整モデルの形式に分解する。ここで $t$ : 時刻（月 単位)。T $(t ; k)$ : 次数 $k$ の階差モデルによる傾向成分で, 本論文ではこれを傾向線（トレンド）とする。 $S(t ; l)$ : 次数 $l$ の季節変動モデルによる季節変動成分。 $A R(t ; m)$ :
次数 $m$ の自己回帰モデルによる定常 AR 成分。定常 $\mathrm{AR}$ 成分はトレンド成分のような長期的変動ではなく, 短 期的な変動成分を表す。 $W(t)$ : 測定ノイズ成分。各成 分に対して仮定されるモデルの詳細については, 文献 (Akaike et al., 1985) にゆずる。

我々は, 水温時系列に対して季節調整モデル（式（1） の次数 $k, l, m$ の組み合わせを変えながら, 赤池情報量規 準 $(A I C)$ を計算した。その中で $A I C$ が最小の季節調整 モデルが，水温時系列に対して最も適合度が高いと判断 して採用した。そして, 傾向成分に一次回帰直線をあて はめ, その傾きを水温上昇率とした。

なお, $S(t ; l)$ には, 前述のとおり, 熱収支による季節 変動のほかに人為的水位操作に伴う季節変動も含まれ る。また, $T(t ; k)$ には, 長期的な温暖化による「趨勢」 に加えて, 定常 AR 成分でも表現できない周期 1 年以上 の「循環」的要素が含まれる可能性がある。陸水応答の 分野では, 観測值から趨勢と循環的要素の影響を分離し, 循環的要素とエルニーニョ現象との対応関係を評価する 試みがなされている。たとえば, Arpe et al.（2000）は 1837 年から 1997 年のカスピ海年平均水位と南方振動指 数がよく合うことを数值実験も用いて調べ, 水位変動と エルニーニョ現象との関係性を指摘している。また，陸 水ではないが, 1997-1998 年のエルニーニョ現象で発生

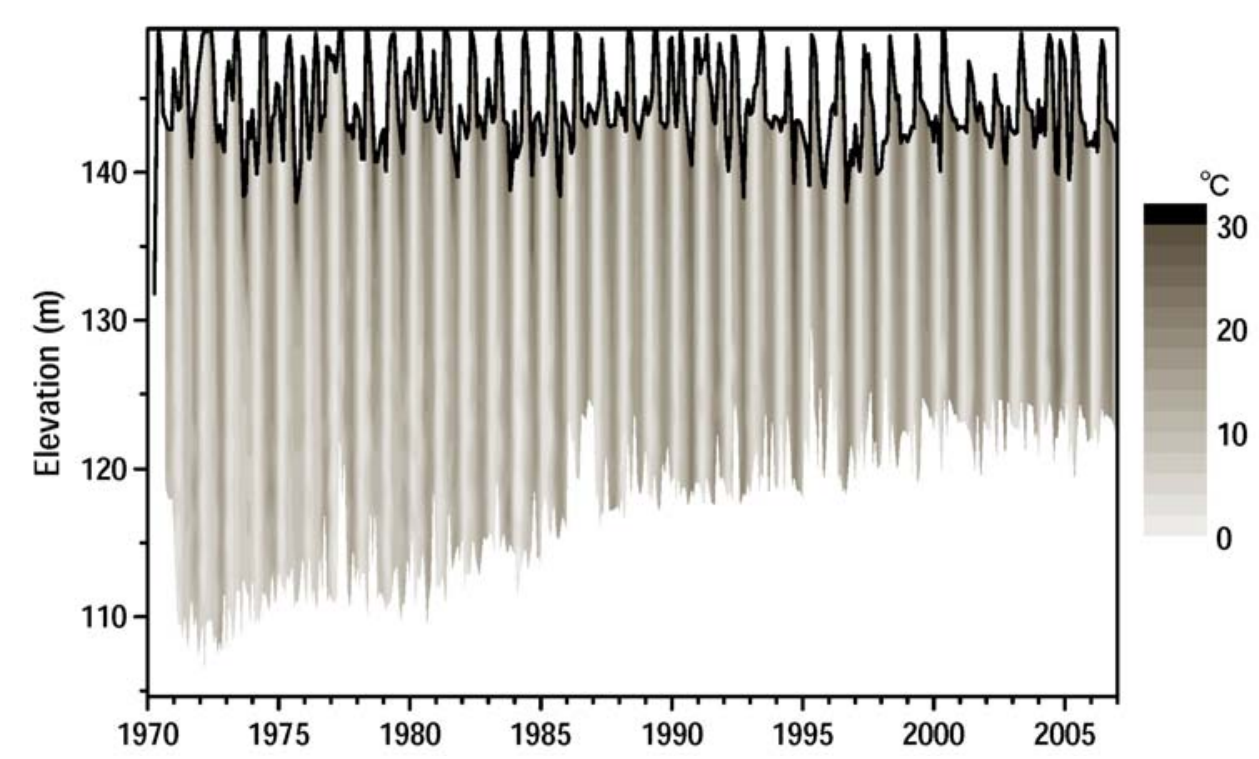

Fig.2. Isothermal plot of Kamafusa Dam Reservoir. Data were obtained from "Management Annual Report of Multipurpose Dams (Tamokuteki Daти Kanri Nenpou)" (River Bureau of Ministry of Construction, 1961-1997) and "Database of Dams (Damu Shoryou de-tabe-su)" (Ministry of Land, Infrastructure, Transport and Tourism).

図 2 釜房ダム湖の等水温図. 水温データは多目的ダム管理年報（建設省河川局，1961-1997）とダム諸 量データベース（国土交通省）から引用した. 
した高海水温の特異性を，1903-1999 年の海面水温デー タセットとの対比により調ベた研究（Lough, 2000）も 行われている。いずれの研究でも，十分に長い観測デー タを使ってエルニーニョ現象と観測值との対応について 検討を行っている。最長でも50 年程度のダム湖水温記 録から，趨勢と循環的要素を分離し，循環的要素の原因 について評価する研究は今後の課題である。

\section{結果と考察}

\section{釜房ダムの事例}

Fig.2 は前処理後の水温年表データから作成した, 釜 房ダム湖の等水温図である。水温は月一回観測されてい る。1970 年に定義された観測層深度の定義は, $0.1 \mathrm{~m}, 0.5$

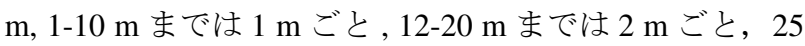
$\mathrm{m}$ からは $5 \mathrm{~m}$ ごとである。ただし，観測年によって観 測されていない層もある。Fig.2 の黒線は水面水位であ り, 最も上の観測層（深度 $0.1 \mathrm{~m}$ ）にほぼ対応する。また, 釜房ダムでは砂の堆積が進んでいるため最深部標高は一 定ではない。Fig.2 から釜房ダムの夏の水温は，1985 年 以降，全層にわたって上昇傾向にあることが明瞭に読み 取れる。
Fig. 3 は釜房ダム湖の最下層の水温変化を, 傾向線（ト レンド), 季節変動成分, 短期的変動成分 (定常成分), ノイズに分離した結果を示している。トレンド成分, 季 節成分, 定常 $\mathrm{AR}$ 成分の次数 $k, l, m$ はそれぞれ $1,2,2$ で ある。また，傾向成分（扊色線）にあてはめた直線（黒 実線）と，その傾きから求めた水温上昇率も記入してい る（Fig.3（b))。この例では水温上昇率は $+1.19^{\circ} \mathrm{C}(10 \mathrm{y})^{-1}$ となり，高い上昇率を示した。

しかし，傾向線と， あてはめた直線とを比べると，年 代により水温上昇率が異なることがわかる（Fig.3（b)）。 1970-1984 年までの水温上昇率は 1970-2006 年の全期間 の水温上昇率（黒実線）とほぼ一致する。1985-1990 年 の傾向線にあてはめた直線（破線）が示す水温上昇率は $2.78{ }^{\circ} \mathrm{C}(10 \mathrm{y})^{-1}$ であり, 全期間の水温上昇率の 2.3 倍で ある。1991-2006 年の傾向線にあてはめた直線（一点鎖 線）が示す水温上昇率は $0.31{ }^{\circ} \mathrm{C}(10 \mathrm{y})^{-1}$ である。この 上昇率は全期間の水温上昇率の約 $1 / 3$ である。このよう に, 季節調整法を使って傾向線を得ることで, 年代間の 上昇率の違いを比較することが容易になる。

なお，釜房ダム最下層水温が堆砂による湖底上昇の影 響を受けていた可能性があるが, その影響の解析は今後 の課題である。

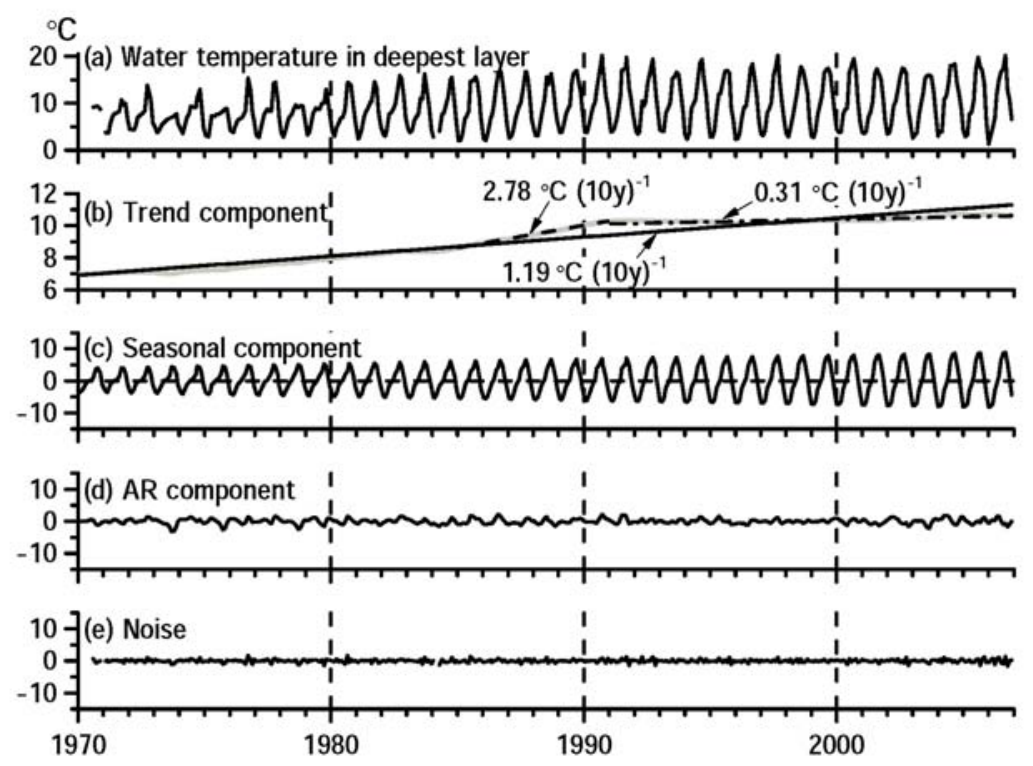

Fig.3. De-composition of water temperature time-series at deepest layer of Kamafusa Dam Reservoir. (a)Monthly water temperature, (b)trend line (gray line), (c) seasonal component, (d) steady autoregressive (AR) component and (e)noise. Solid, broken and dashed-dotted lines denote regression lines for 1970-2006, 1985-1990 and 1991-2006, respectively.

図 3 釜房ダム湖最下層の水温時系列の分解例.（a）月ごとの水温変化, (b) 傾向成分 (トレンド成分) ( 灰 色線 ），(c) 季節成分，（d）定常 AR 成分, (e) ノイズ.（b）の黒実線, 破線, 一点鎖線は, 1970-2006 年, 1985-1990 年, 1991-2006 年の傾向成分に対する回帰直線. 


\section{長尾正之ほか}

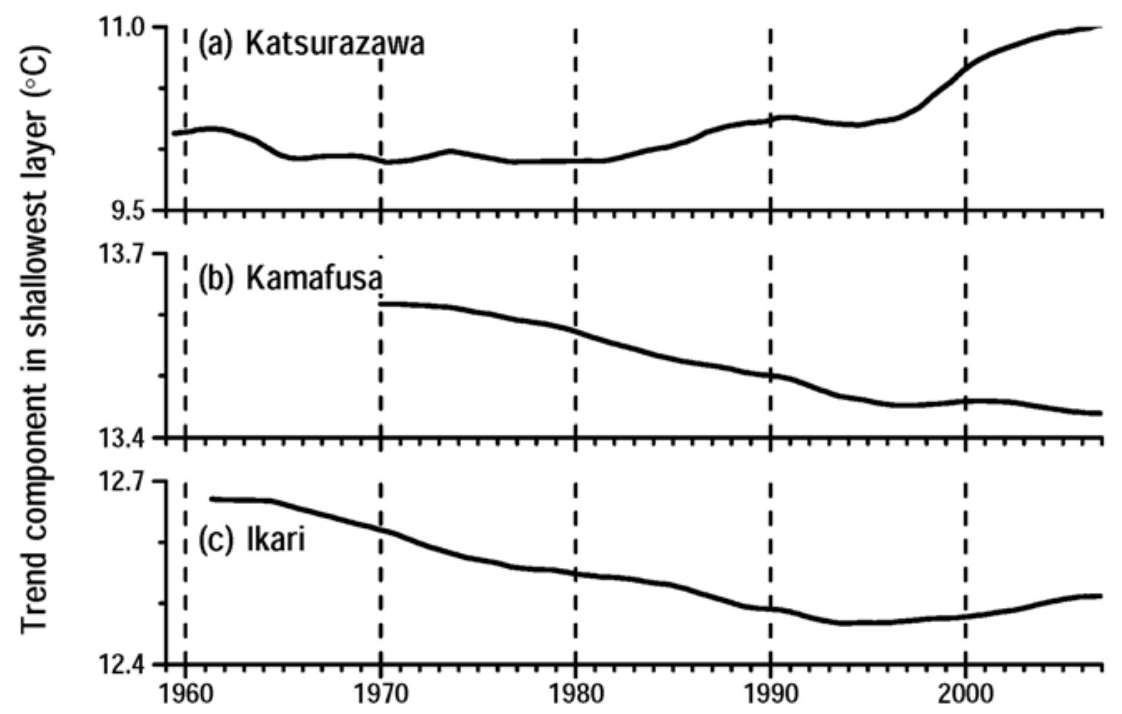

Fig.4. Long-term trend lines of water temperatures at shallowest layers in Katsurazawa, Kamafusa, and Ikari Dam Reservoirs.

図 4 桂沢, 釜房, 五十里ダム湖の最表層水温の長期的傾向.

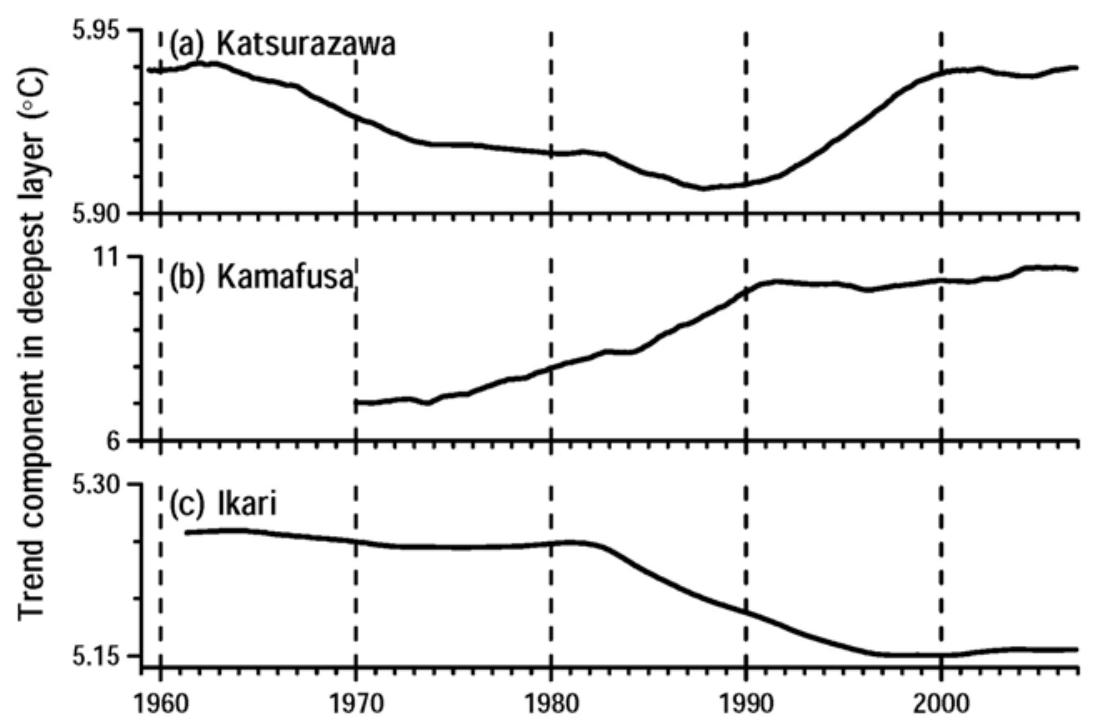

Fig.5. Long-term trend lines of water temperatures at deepest layers in Katsurazawa, Kamafusa, and Ikari Dam Reservoirs.

図 5 桂沢, 釜房, 五十里ダムの最下層水温の長期的傾向.

\section{長期的傾向}

1960 年代あるいは 1970 年代以降からダム水温記録を 持つ桂沢, 釜房, 五十里ダムの水温の傾向線（トレンド） をFig.4 と Fig.5 に示した。傾向線は, 最表層は Fig.4, 最下層は Fig.5 に表し, さらにダムごとに表示を分けた。 傾向線の最大最小の範囲に合わせて Fig.4 と Fig.5 の縱 軸は調整した。
傾向線の変動幅がダムごとに大きく違うので，定性的 な水温傾向線の特徴だけをここでは列挙する。

桂沢ダムの最表層水温の傾向線をみると，1985 年以 前は比較的変化は少ない。1985 年から 1990 年にかけて 水温は急上昇している。1991 年から 1995 年には水温は 低下傾向にある。1996 年以降は水温が急上昇している。 桂沢ダムの最下層水温の傾向線をみると, 1990 年ごろ 
までは水温は低下傾向にある。1991 年から 2000 年まで は急激な水温上昇を示している。2001 年以降の水温変 化はほとんどない。また, 最表層では傾向線の変動幅は

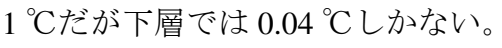

釜房ダムの最表層水温の傾向線をみると, 1970 年以 降，水温は低下傾向にある。1995 年以降はそれより前 の年代よりも低下率は小さくなっている。釜房ダムの最 下層水温の傾向線の特徵は前述したのでここでは省略す る。また，桂沢ダムと異なり，釜房ダムでは最表層では

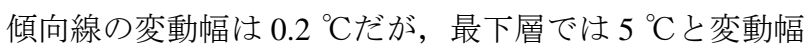
が大きい。

五十里ダムの最表層水温の傾向線をみると, 1994 年 までは低下傾向であり，1995 年以降は上昇傾向に転じ ている。また, 五十里ダムの最下層水温の傾向線では, 1981 年までは弱い水温低下傾向にあり, 続く 1982-1995 年まではそれ以前に比べて急激な水温低下傾向を示して いる。1996-1999 年までは横ばい傾向で, 2000 年以降は わずかに上昇傾向にある。

長期的傾向について, 桂沢, 釜房, 五十里ダム湖の水
温上昇率を, Fig.4, 5 の傾向線を使用し，1970-2006 年に 対して計算した（Table 2)。最表層水温については, 桂 沢が地方の気温上昇率を上回る水温上昇率を示した。釜 房と五十里は逆に低下傾向を示した。最下層水温につい ては，桂沢と釜房で正の水温上昇率を示した。特に釜房 では気温上昇率を大きく上回っていた。五十里の最下層 水温は最表層水温と同様に低下傾向を示していた。

\section{短期的傾向}

長期傾向を三つのダムから調べた結果，概して，1980 年代以降または 1990 年代以降と, それ以前の年代で は, 水温傾向が変わっているように見える。そこで, 1993-2006 年の 14 年間に調查期間をそろえ, この期間 に水温記録を持つ主なダムについて, 1990 年代以降の 最表層と最下層の水温の短期的傾向を調べた（Table 2)。 桂沢については，1993-2006 年のデータでは最良の季節 調整モデルが定まらなかったので，1959-2006 年の長期 傾向の解析で得た傾向線を用い, その線の 1993-2006 年 の範囲に直線をあてはめ, その勾配を短期的傾向の上昇

Table 2 Trends of water temperature for each dam reservoir.

表 2 ダム湖の水温の傾向。

\begin{tabular}{|c|c|c|c|c|c|c|c|c|c|c|c|c|c|}
\hline \multirow{3}{*}{ Dam Name } & \multirow{3}{*}{ Prefecture } & \multirow{3}{*}{$\begin{array}{l}\text { Analyzed } \\
\text { period }\end{array}$} & \multicolumn{5}{|c|}{ Shallowest layer } & \multicolumn{5}{|c|}{ Deepest layer } & \multirow{3}{*}{$\begin{array}{l}\text { Rate of air- } \\
\text { temperature } \\
\text { rise } \\
{ }^{\circ} \mathrm{C}(10 \mathrm{y})^{-1}\end{array}$} \\
\hline & & & \multirow{2}{*}{$\begin{array}{l}\text { Average } \\
{ }^{\circ} \mathrm{C}\end{array}$} & \multirow{2}{*}{$\begin{array}{l}\text { Rate of rise } \\
{ }^{\circ} \mathrm{C}(10 \mathrm{y})^{-1}\end{array}$} & \multicolumn{3}{|c|}{ Order } & \multirow{2}{*}{$\begin{array}{l}\text { Average } \\
{ }^{\circ} \mathrm{C}\end{array}$} & \multirow{2}{*}{$\begin{array}{l}\text { Rate of rise } \\
{ }^{\circ} \mathrm{C}(10 \mathrm{y})^{-1}\end{array}$} & \multicolumn{3}{|c|}{ Order } & \\
\hline & & & & & $k$ & $l$ & $m$ & & & $k$ & $l$ & $m$ & \\
\hline \multirow{2}{*}{ Katsurazawa } & \multirow{2}{*}{ Hokkaido } & $1970-2006^{*}$ & 10.2 & +0.30 & 1 & 1 & 2 & 5.9 & +0.01 & 1 & 1 & 1 & \multirow{4}{*}{+0.106} \\
\hline & & $1993-2006 * *$ & 10.6 & +0.73 & - & - & - & 5.9 & +0.02 & - & - & - & \\
\hline \multirow{2}{*}{ Kamafusa } & \multirow{2}{*}{ Miyagi } & 1970-2006 & 13.5 & -0.06 & 1 & 1 & 2 & 9.1 & +1.19 & 1 & 2 & 2 & \\
\hline & & 1993-2006 & 13.3 & +0.03 & 1 & 1 & 1 & 10.4 & +0.03 & 1 & 1 & 1 & \\
\hline \multirow{2}{*}{ Ikari } & \multirow{2}{*}{ Gunma } & $1970-2006^{*}$ & 12.5 & -0.03 & 1 & 1 & 2 & 5.2 & -0.04 & 1 & 1 & 2 & \multirow{3}{*}{+0.110} \\
\hline & & 1993-2006 & 12.4 & +0.35 & 1 & 1 & 0 & 5.0 & +0.01 & 1 & 1 & 3 & \\
\hline Iwaya & Gifu & 1993-2006 & 15.1 & +0.02 & 1 & 1 & 1 & 8.7 & -1.09 & 1 & 1 & 2 & \\
\hline Hitokura & Hyougo & 1993-2006 & 17.9 & +0.01 & 1 & 1 & 1 & 9.0 & -0.00 & 1 & 1 & 4 & \multirow{4}{*}{+0.115} \\
\hline Haji & Hiroshima & 1993-2006 & 16.5 & +0.04 & 1 & 1 & 1 & 10.5 & +2.36 & 1 & 1 & 2 & \\
\hline Sameura & Kouchi & 1993-2006 & 17.2 & +0.77 & 1 & 1 & 0 & 7.1 & +0.62 & 1 & 1 & 2 & \\
\hline Matsubara & Ooita & 1993-2006 & 17.5 & +0.01 & 1 & 1 & 1 & 14.1 & -0.02 & 1 & 1 & 1 & \\
\hline Aha & Okinawa & 1993-2006 & 23.4 & +0.67 & 1 & 1 & 0 & 16.0 & +0.48 & 1 & 1 & 0 & +0.103 \\
\hline Hyugami $^{* *}$ & Fukuoka & $1962-2008$ & - & +0.21 & - & & & - & +0.88 & - & & & $\begin{array}{c}0.115 \\
(0.32)^{\#}\end{array}$ \\
\hline
\end{tabular}

* For Katsurazawa and Ikari Dam Reservoirs, rates and averages of temperature rise and average were determined using trend lines only from only 1970 to 2006 in Figs. 4 and 5.

** Rate and average of temperature of Katsurazawa Dam Reservoir from 1993 to 2006 were obtained using trend line from 1959 to 2006.

*** By Ikeura et al. (2008) with linear regression analysis.

**** Cited from Table 2.1.3 in "Extreme Weather Report 2005 (Ijou Kishou Report 2005)" (Japan Meteorological Agency, 2005).

\# At dam site of Hyugami Dam Reservoir (Ikeura et al., 2008). 


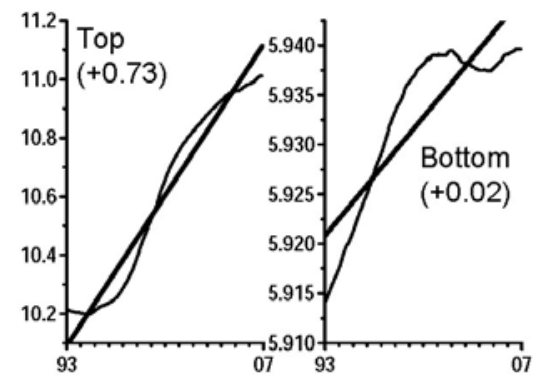

(a) Katsurazawa

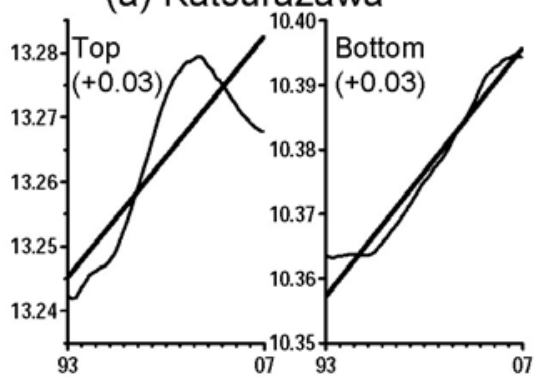

(b) Kamafusa

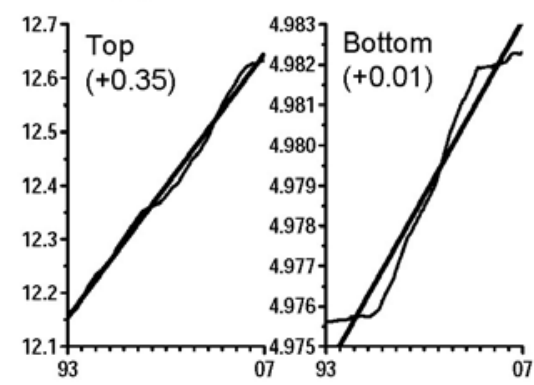

(c) Ikari

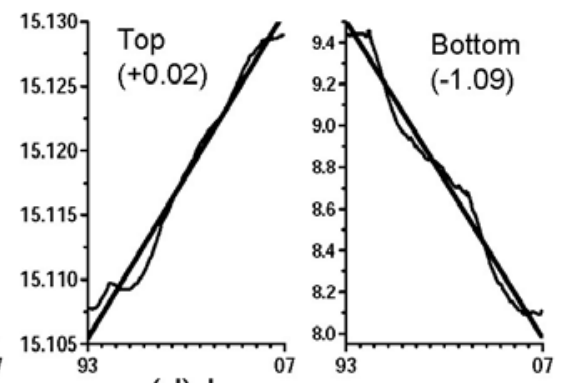

(d) Iwaya

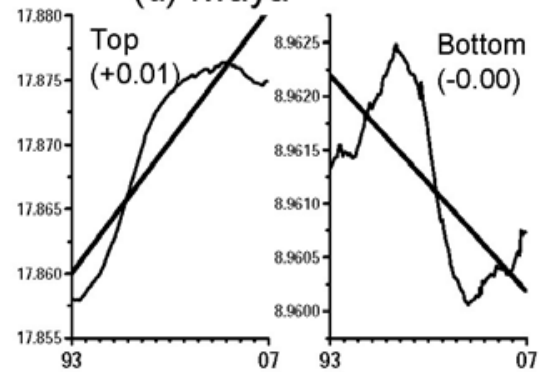

(e) Hitokura

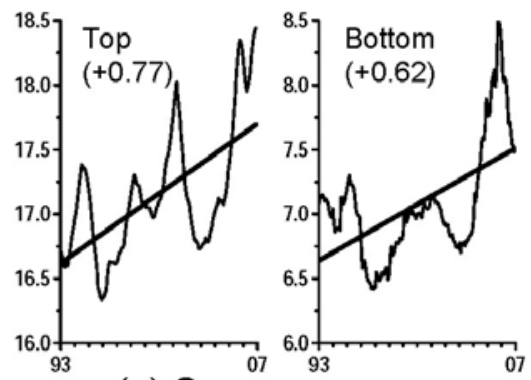

(g) Sameura

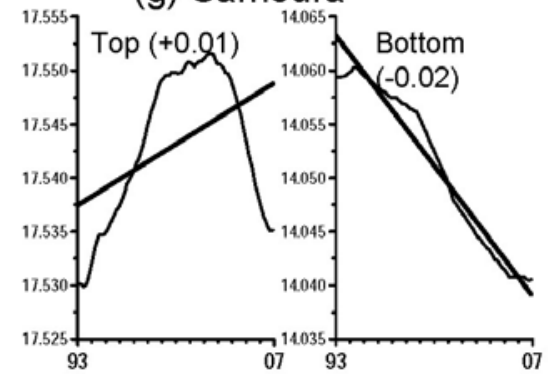

(h) Matsubara

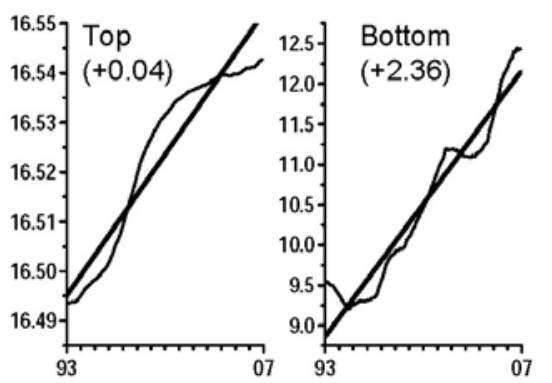

(f) Haji

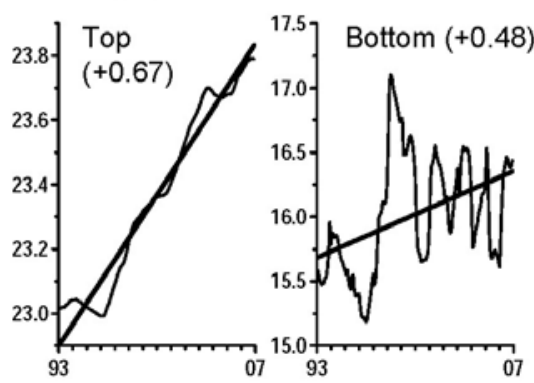

(i) Aha

Fig.6. Short-term trend lines (thin lines) and their regression lines (thick lines) of water temperatures at shallowest and deepest layers in each dam reservoir. Analyzed period ranges from 1993 to 2006. Values in brackets are rates of temperature rises $\left({ }^{\circ} \mathrm{C}(10 \mathrm{y})^{-1}\right)($ Table 2$)$.

図 6 各ダム湖における最表層と最下層の水温傾向成分（細線）とその回帰直線（太線）。解析期間は 1993-2006 年. カッコ内の数值は水温上昇率 $\left({ }^{\circ} \mathrm{C}(10 \mathrm{y})^{-1}\right)$ (表 2).

率とした。また，Fig.6は，1993-2006 年の最表層と最下 層のダムの傾向線と, あてはめた一次回帰直線を示して いる。平均水温は, 短期的傾向解析で得られた傾向線の 1993-2006 年の平均をとり計算した（ただし桂沢ダムだ けは長期的傾向の解析で得られた傾向線の 1993-2006 年 の結果を利用した)。

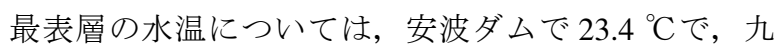
州から東北に向からにつれて温度が下がり, 桂沢ダムで $10.6{ }^{\circ} \mathrm{C}$ とっていて, 緯度が高くなるにつれて平均水温 が低下している。短期的傾向の水温上昇率をみると，す ベてのダムで水温上昇率は正だった。また, 最も上昇率 が高かったダム湖は早明浦ダム $\left(+0.77{ }^{\circ} \mathrm{C}(10 \mathrm{y})^{-1}\right)$ で, 次いで, 桂沢ダム $\left(+0.73{ }^{\circ} \mathrm{C}(10 \mathrm{y})^{-1}\right)$, 安波 $\left(+0.67{ }^{\circ} \mathrm{C}\right.$ $\left.(10 \mathrm{y})^{-1}\right)$, 五十里 $\left(+0.35{ }^{\circ} \mathrm{C}(10 \mathrm{y})^{-1}\right)$ の順となっていた。 最表層の水温上昇率がすべて正だったことは, 近年, 気 温が上昇傾向にあること（気象庁，2005）を，反映して いるためと考えられた。なお, 桂沢, 五十里, 早明浦, 安波ダムでは水温上昇率が, それぞれの地方の気温上昇 率を上回った。この原因は本研究では明らかにはならず, 今後の課題として残された。

一方，気温の上昇傾向や気象影響を比較的受けにくい 最下層の水温の上昇率をみると, それが正のダム湖と負 のダム湖とが存在した。

最下層で水温上昇率が正だったダム湖のうち, 上昇率 が最大だったダム湖は土師 $\left(+2.36{ }^{\circ} \mathrm{C}(10 \mathrm{y})^{-1}\right)$ で, 次い で早明浦 $\left(+0.62{ }^{\circ} \mathrm{C}(10 \mathrm{y})^{-1}\right)$, 安波 $\left(+0.48{ }^{\circ} \mathrm{C}(10 \mathrm{y})^{-1}\right)$, 
釜房 $\left(+0.03{ }^{\circ} \mathrm{C}(10 \mathrm{y})^{-1}\right)$, の順であった。また, 地方ご との気温上昇率を上回る水温上昇率を最下層で示したダ ム湖は, 土師, 早明浦, 安波だった。

気温上昇率を上回る高い底層水温の上昇率の原因とし て，堆砂による湖底上昇や冬季鉛直混合の弱まりが指摘 されている。池浦ら（2008）は，日向神ダムの底層水温 が 1980 年代後半から $0.88{ }^{\circ} \mathrm{C}(10 \mathrm{y})^{-1}$ でありダム地点の 気温上昇率 $0.32{ }^{\circ} \mathrm{C}(10 \mathrm{y})^{-1}$ を超えていること，同ダム湖 では堆砂が進んでおり，これが底層の冷水層を近年頻繁 に消滅させ最下層水温の高い上昇率の原因になった可能 性があることを指摘している。一方，速水・藤原（1999） は，1964 年から 1997 年までの琵琶湖北湖深層水温の上 昇率が $0.40{ }^{\circ} \mathrm{C}(10 \mathrm{y})^{-1}$ であり彦根の月平均気温の上昇率 $0.30{ }^{\circ} \mathrm{C}(10 \mathrm{y})^{-1}$ を上回っていること, この原因が暖冬化 よる冬季鉛直混合の弱まりによることを数值実験に基づ き示している。堆砂による湖底上昇や冬季鉛直混合の弱 まりは, 本研究で最下層水温の上昇率が高かったダム湖 でも起こっている可能性があり, その定量的な評価は今 後の検討課題である。

一方, Hondzo and Stefan（1991）は規模の異なる 3 湖 沼で平常年と温暖年の水温の解析を行い，面積が広い 2 湖では表層・深層ともに秋まで高温が続いたが，面積が もっとも狭い湖では深層水温が低下したことを報告して いる。この原因は水温躍層が強固になることが主因と考 えられたが，狭い湖が潜窪を持つことも関係していると 思われた（新井，2000）。

本研究で最下層水温が低下傾向を示した岩屋, 一庫, 松原のダム湖についても, 水温躍層の経年変動と底層水 温の低下との関係を，今後検討する必要がある。

\section{まとめ}

日本の地方ごとにダム湖 9 箇所を選び，最表層と最下 層の水温時系列について, 季節要因や短期変動の影響を 避け，傾向成分だけを抽出できる時系列解析法（季節調 整法）を使い，ダム湖の最表層と最下層の水温の傾向成 分を求めた。

1970 年代以前に作られ，長い水温記録を持つ三つの ダム湖の傾向成分によると，1980 年代以降または 1990 年代以降と, それ以前の年代では, 水温傾向が変わって いることがわかった。

1993 年から 2006 年の水温について, 全国 9つのダム 湖を調べたところ，最表層水温には気温上昇が理由と思 われる水温上昇が全てのダム湖で認められ，一部に，気
温上昇率を上回る水温上昇率を持つダム湖も存在した。 最下層水温に関しては，上昇傾向と下降傾向のダム湖が 存在した。最下層水温の結果が一様でなかった理由は, 堆砂による湖底上昇, 冬季鉛直循環の弱まり, 水温躍層 の強まりなどに影響されているためと考えられた。それ らを個々のダム湖ごとに検討し，影響を分離することが 今後の検討課題である。

\section{謝 辞}

国交省図書館, 国総研図書館, 土木図書館, 東京大 学工学・情報理工学図書館からは, 多目的ダム管理年報 の閲覧等についてご支援をいただいた。産総研地質情報 研究部門 安永恵三子氏には, 水温年表の入力, 異常值 確認など, データ整備全般を行っていただいた。統計数 理研究所佐藤整尚准教授からは, TIMSAC for R package の時系列分解プログラム decomp について詳しくご説明 をしていただいた。名古屋工業大学 長尾正志名誉教授 からは 時系列解析全般についてご意見をいただいた。 査読者ならびに担当編集委員からの多数のご意見によ り, 論文が改善された。以上, 記して感謝の意を表する。 また, 長年にわたりダムの水温年表の作成を続けて来ら れた各ダム管理者と観測担当者に敬意を表する。なお, 本研究は, 環境省公害防止等試験研究費の一環として実 施されたほか，一部は科研費（課題番号：19560526）の 助成を得て行われた。

\section{文 献}

Akaike, H., T. Ozasaki, M. Ishiguro, Y. Ogata, G. Kitagawa, Y.-H. Tamura, E. Arahata, K. Katsura, and Y. Tamura (1985): TIMSAC-84 Part 1 \& Part 2. Computer Science Monographs, No.22 \& 23, The Institute of Statistical Mathematics, Tokyo.

新井 正 (2000)：地球温暖化と陸水水温. 陸水学雑誌, 61:25-34.

Arpe, K., L. Bengtsson, G. Golitsyn, I. Mokhov, V. Semenov and P. Sporyshev(2000): Connection between Caspian sea level variability and ENSO. Geophysical Research Letters, 27:2693-2696.

Charlton, M., M. Giddings, C. Holmes, W. Carmichael and J. Ridal(2001): Algal toxins and taste and odour. In Threats to sources of drinking water and aquatic ecosystems health in 
Canada. NWRI Scientific Assessment Report Series Report No.1., Environment Canada(ed.):5-8, National Water Resources Research Institute, Burlington.

Hall, G.V., R.M. D'Souza and M.D. Kirk(2002): Foodborne disease in the new millennium: out of the frying pan and into the fire?. The Medical Journal of Australia, 177:614-618.

速水祐一・藤原建紀（1999）：琵琶湖深層水の温暖化. 海の研究, 8:197-202.

Hondzo, M. and H.G. Stefan(1991): Three case studies of lake temperature and stratification response to warmer climate. Water Resources Research, 27:1837-1846.

茨城県生活環境部環境対策課（2007）：平成 18 年度霞ヶ 浦の水質概況について.

茨城県生活環境部環境対策課（2008）：平成 19 年度霞ヶ 浦の水質概況について.

茨城県生活環境部環境対策課（2009）：平成 20 年度霞ヶ 浦の水質概況について.

池浦太莊・一木謙次 - 竹田智和 (2008)：日向神ダ 么湖水温の経年変動. 福岡県保健環境研究所年報, 35:83-89.

IPCC(2007): Climate Change 2007: Impacts, Adaptation and Vulnerability. Contribution of Working Group II to the Fourth Assessment Report of the Intergovernmental Panel on Climate Change, M.L. Parry, O.F. Canziani, J.P. Palutikof, P.J. van der Linden and C.E. Hanson(Eds.), Cambridge University Press, Cambridge.

建設省河川局（1961-1997）：多目的ダム管理年報（第 3 回 昭和 34 年一第 36 回平成 4 年).

気象庁（2005）: 異常気象レポート2005 近年における 世界の異常気象と気候変動. 気象業務支援センター, 東京.
国土交通省：ダム諸量データベース. http://www2.river. go.jp/dam/index.html (2009 年 11 月 2 日)

Kumagai, M., K. Ishikawa and J. Chunmeng(2002): Dynamics and biogeochemical significance of the physical environment in Lake Biwa. Lakes \& Reservoirs: Research and Management, 7: 345-348.

Lough, J.M.(2000): 1997-1998: Unprecedented thermal stress to coral reefs?. Geophysical Research Letters, 27:3901-3904.

Moulton, R. and D. Cuthbert(2000): Cumulative impacts/risk assessment of water removal or loss from the Great Lakes - St. Lawrence River system. Canadian Water Resources Journal, 25:181-208.

日本ダム協会（2008）：ダム年鑑 2008. 日本ダム協会, 東京.

日本ダム協会：ダム便覧. http://wwwsoc.nii.ac.jp/jdf/ Dambinran/binran/TopIndex.html（2009 年 11 月 2 日）

日本河川協会：日本河川図. http://www.japanriver.or.jp/ river_law/map.htm (2009 年 11 月 2 日)

岡本高弘 - 奥田一臣 - 小林博美 - 矢田稔 - 原 良平 - 石 川俊之・中村豊久 (2007) : 2006 年度冬季（2007 年 1 月〜 3 月）の琵琶湖北湖の水質変動について. 滋 賀県琵琶湖環境科学研究センター試験研究報告書, 3:125-129.

Robarts, R., M. Kumagai and C.H. Magadza(2005): Climate change impacts on lakes: technical report of the session 'Ecosystem Approach to Water Monitoring and Management' organized at the World Water Forum II in Kyoto. Climatic Change Ecosystem Approach to Water Monitoring and Management, UNEP Publication, Nairobi. 統計数理研究所 : TIMSAC for R package. http://cran.r-project. org/web/packages/timsac/index.html（2009 年 11 月 2 日） 